\title{
Um olhar interdisciplinar para o ser-educador
}

\section{An interdiciplinary look at the educator}

\author{
Raquel Gianolla MIRANDA*
}

Resumo: Neste artigo, discutem-se questões atuais que permeiam o sentido de ser do educador dentro de uma perspectiva interdisciplinar de análise e estudo. Busca-se refletir sobre seu compromisso com a sociedade em que vive e com seu crescimento pessoal. Parte-se da questão que indaga qual seria o alimento que nutre um educador em sua profissão e discute-se, também, sua identidade como facilitador ou questionador da aprendizagem, dentro de sua prática em sala de aula.

Palavras-chave: educação. interdisciplinaridade. professor-questionador.

Abstract: This article discusses the current issues that permeate the meaning of being an educator in an interdisciplinary perspective of analysis and study. It attempts to reflect on the commitment of the educator with the society and the personal growth. Part of the question that enquires which would be the professional nourishment for the educator,discussing his identity as a facilitator or questioner of the learning processes, taking into account the experience in the classroom.

Keywords: education. interdisciplinarity. teacher-questioner.

Eu vejo e transvejo o mundo Os perfumes eu chego a escutar Dos sons eu apalpo as formas Misturo todos os sentidos

Assim, eu salvo as palavras Que estejam fatigadas de informar.

\footnotetext{
* Graduada em Análise de Sistemas Administrativos de Processamento pela Pontifícia Universiade Católica de Campinas. Mestre em Educação. Docente da UNISO - Universidade de Sorocaba e da UNIMEP - Universidade Metodista de Piracicaba, em parceira com o Senai. E-mail: rg.miranda@uol.com.br
}

Olhar de professor, Ponta Grossa, 9(1):113-118, 2006. 
Sobre esse tema, Quintás (2000), em seu artigo "El secreto de una ensenanza eficaz", utiliza-se de uma metáfora - o alimento - para nos perguntar sobre o que nos faz profissionais comprometidos, ou seja, o que nos move como educadores, qual o sentido da nossa profissão na nossa vida?

Tal como o alimento de que nosso corpo necessita para desenvolver suas funções vitais, nossa profisssão necessita de uma força que dê sentido aos nossos atos, que não nos deixe recuar, que nos mova para a utopia da mudança e da transformação. Alimento esse que simboliza o meio que utilizamos para dar sentido às ações educacionais, que nos nutre de idéias e ideais.

Fazenda (1994,p.31) nos indica que o alimento que move um professor interdisciplinar tem um gosto especial no que diz respeito ao conhecer e pesquisar. Ele alimenta-se do mundo e das idéias através do olhar atento, da investigação curiosa, da leitura, do contato, dos sentidos. Com isso, transforma e dá significado, nutre.

Esse mesmo professor que se alimenta de coragem, ousa ao utilizar novas técnicas e procedimentos de ensino, antes analisados e dosados convenientemente. Não se adapta, transforma; não se contenta, age; não se deixa enganar, erra e aprende. Seus atributos principais são: envolvimento e compromisso. Porém, todo esse comprometimento o faz defrontar-se com obstáculos de ordem institucional, incomodando os que têm a acomodação por propósito. Sua marca é a resistên- cia.

Mas, nesse movimento de ingestão e deglutição, se todo o alimento só nos serve e nos faz mais fortes, de nada adianta toda a minha saúde intelectual se não entro na dança e no exercício de gastar toda essa energia com o outro, na prática, num sentido do $\mathrm{Eu}-\mathrm{Tu}$ (BUBER, 1974).

Se o alimento que nutre minhas idéias, que aprofunda minhas reflexões, perde-se na limitação do meu corpo, do meu ego, perde também sua direção. Necessita servir de alimento, para ser compartilhado, para fazer sentido. E é na dança desse movimento de alimentar-se e alimentar que percebo que "toda essa experiência que um indivíduo tem com o outro é função do encontro que ele tem consigo próprio" (BUGTENDIJK apudFAZENDA, 1994, p. 55)

Então, é preciso que todo o meu corpo fale coerentemente com o que penso. Que cada palavra dita, cada gesto seja cuidadoso e que esteja pleno de significado. Não temos tempo nem prazer nas superficialidades, nas falsas intenções, nos medos, nos interesses individualistas, na hipocrisia.

Um alimento tem de expandir nossas intenções e abrir espaço para absorver o sentido do outro, do mundo, significando-o. Nutre, então, quem se aproxima, envolvendo-o pela mesma intenção e percepção de que não sou sem que o outro também seja.

Isto é o que me interessa: que descubras em ti mesmo o que queres, as imensas possibilidades que tem o teu ser 
(todo o teu ser) quando o analisamos com uma inteligência penetrante. (QUINTÁS, 2000)

É através desse movimento, do círculo virtuoso/vicioso de alimentar-se e alimentarmos, que provamos o verdadeiro gosto do sentido da educação. Um alimento que só se multiplica ao ser dividido, em um processo no qual a "tônica que nos envolve é o diálogo e a marca, o encontro, a reciprocidade”. (FAZENDA, 1994, p. 49$50)$.

Ainda segundo Fazenda, "o diálogo supõe que realmente ocorra uma atitude de abertura, uma relação de reciprocidade, de amizade e de receptividade, que basicamente só poderá ocorrer se houver antes uma intenção de conhecer o outro". (idem, p.56)

A reciprocidade - que implica troca ou permuta, ou que supõe permuta entre duas pessoas ou grupos, ação mútua (AURÉLIO, 1988) - requer a intenção de conhecer e conhecer-se, num jogo de ida e volta, de emissor e receptor, do eu e o tu formando um nós, de intencionalidade comum.

Dentro desse processo de alimentar e ser alimentado, através da troca e do diálogo, pensando no contexto em que a escola se encontra, Quintás se refere à necessidade de se assumir e discutir o ambiente social em que estamos inseridos, o qual é repleto de estímulos e informações escritas, sonoras, imagéticas, faladas, balbuciadas, reais, virtuais, magnéticas e cibernéticas. Escreve sobre a dificuldade em discernir, refletir, discutir e se- lecionar o "que é conveniente assumir e o que é conveniente rechaçar" (Quintás, 2000). Nas palavras de Hanna Arendt:

A educação é o ponto em que decidimos se amamos o mundo o bastante para assumirmos a responsabilidade por ele e, com tal gesto, salvá-lo da ruína que seria inaceitável não fosse a renovação e a vinda dos novos e dos jovens. A educação é também onde decidimos se amamos nossas crianças o bastante para não expulsá-las de nosso mundo e abandoná-las a seus próprios recursos, e tampouco arrancar de suas mãos a oportunidade de empreender alguma coisa nova e imprevista para nós, preparando-as, em vez disso com antecedência para a tarefa de renovar um mundo comum (ARENDT, 1992, p.247).

Em meio a esses estímulos, parte do discurso educacional de hoje define como "professor facilitador" o educador que deveria considerar e relacionar todos esses sentidos na sala de aula, numa tentativa de traduzir o meio social e discuti-lo, inserindo-o, assim, na aprendizagem escolar.

Facilitar quer dizer tornar ou fazer fácil, ou mais fácil; apresentar uma coisa como muito mais fácil do que é na realidade; pôr à disposição, facultar; agir com imprevidencia; exporse, descuidar-se; prontificar-se, prestar-se; adquirir facilidade. (FERREIRA, 1999) [grifo meu].

Ao contrário, porém, penso que a expressão mais indicada para se descrever a atitude do professor frente aos desafios do meio social é o de 
"professor questionador", uma vez que questionar tem o significado de fazer ou levantar questão acerca de; discutir, disputar, controverter; retorquir, redargüir. (FERREIRA, 1999).

Então, um professor questionador é aquele que desafia os seus alunos e se desafia, diariamente, a buscar mais, a questionar suas verdades estagnadas, a transver o mundo. Que ultrapassa a leitura externa e atinge o olhar interno sobre si, sobre o mundo, sobre sua relação com o mundo. Que está atento às palavras, aos sentidos, aos olhares, aos gestos. Que imprime um rigor ao pensamento e ao pronunciamento de suas idéias e das idéias de seus alunos. Que dá voz à argumentação, à dúvida, ao erro.

É fundamental, segundo Fazenda (1994, p.45), que o professor seja mestre, "aquele que sabe aprender com os mais novos, porque mais criativos, mais inovadores, porém, não com a sabedoria que os anos de vida vividos outorgam ao mestre". E a autora complementa: "A alegria, o afeto, o aconchego, a troca (...) não podem pedir demissão da escola; sua ausência poderia criar um mundo sem colorido, sem brinquedo, sem lúdico, sem felicidade".

Todo esse ideal de educador vem ao encontro, novamente, das palavras de Hanna Arendt, quando esta define a posição do professor frente ao mundo:

A qualificação do professor consiste em conhecer o mundo e ser capaz de instruir os outros acerca deste, porém sua autoridade se assenta na responsabilidade que ele assume por este mundo. Face à criança, é como se ele fosse um representante de todos os habitantes adultos, apontando os detalhes e dizendo à criança: - Isso é o nosso mundo.(ARENDT, 1992, p. 239).

A questão do compromisso que o professor tem com seus alunos também é abordada por Fazenda (1994), quando se refere às características de um professor bem-sucedido, com relação às atitudes interdisciplinares que, segundo a autora, caracterizam um "sujeito portador de uma atitude

\footnotetext{
${ }^{1}$ Ao pesquisar o melhor termo para definir um professor comprometido com o ato de educar e não só de ensinar, inicialmente pensei na expressão professor dificultador. Ao investigar o significado da palavra dificultar, percebi que esta pode ter um sentido brusco de recusa ou desafeto. Dificultar (Ferreira, 1999) significa tornar dificil ou custoso a fazer; por impedimento ou difuculdade a; representar como difícil; fazer-se dificil; não condescender; recusar-se. Outra expressão pesquisada foi professor mediador (Fazenda,1994), que quer dizer aquele que medeia ou intervém; mediação: ato ou efeito de mediar; intervenção, intercessão, intermédio; intervenção com que se busca produzir um acordo; processo pacífico de acerto de conflitos internacionais, no qual a solução é sugerida e não imposta às partes interessadas. (Ferreira, 1999). Apesar de acreditar na característica mediadora que o professor deve ter, penso que, ao optar pelo termo questionador, este sugere um tom de desafio a se propor, outras visões de um assunto a ser discutido, revelando a dúvida que leva ao conhecimento e à investigação, aspectos importantes para traduzir a diversidade existente na realidade cotidiana, imprimindo uma palavra-ação mais forte e ativa dentro da sala de aula.
}

$\overline{116}$ Olhar de professor, Ponta Grossa, 9(1):113-118, 2006. 
comprometida com todas as suas afirmações e negações". Sendo comprometido com o mundo, é um ser que gosta de conhecer, que busca, que pesquisa, que vive insatisfeito com o que realiza, "com dúvidas a respeito do trabalho que executa". (FAZENDA, 1994, p.49) Nele encontramos a marca do novo, um ser que entende cada momento como único, que ousa nas técnicas e procedimentos de ensino, relacionando sempre o novo com o velho. Ou seja, parte de sua experiência pessoal e profissional, mas é aberto a mudanças, a refletir sobre suas atitudes e possibilidades, a ver e rever-se. Todavia, todo esse envolvimento também é marcado por momentos de solidão, de isolamento, de conflito. (idem)

Dai-me um ponto de apoio e eu levantarei a Terra (Arquimedes).

Essa marca identitária que move o professor interdisciplinar no exercício de sua vida e profissão sugere um compromisso com duas das categorias analisadas por Quintás, Fazenda e Japiassu, que envolvem todo esse ato de educar comprometido: o cuidado rigoroso com o pensar e com a linguagem.

Platão já nos dizia que compreender com os sentidos é só o primeiro passo para o conhecer, pois a partir daí é preciso pensar. $\mathrm{O}$ ato de pensar, como o ato de comunicar, só existe a partir da dúvida e da desinformação (PIGNATARI, 1973), "na contradição entre opiniões para elevar-nos a um ideal de verdade que sempre nos es- capa" (JAPIASSU, 2001, p.10).

Bem sabemos que a dúvida nos leva ao conhecimento; que o erro nos desperta para o aprender; que a instabilidade do saber é a mola propulsora da descoberta; que aprendemos mais quando ousamos errar.

Difícil é percebermos que o ambiente que envolve a aprendizagem na sala de aula, algumas vezes, tende a estar coberto pelo manto das verdades absolutas dos livros didáticos, das certezas, da estabilidade. Então, condenamos o erro (sublinhamos em vermelho), desprezamos as sutilezas encontradas nas respostas inesperadas. $\mathrm{O}$ ambiente do conhecer transformase em previsível, em saber contido.

Se pensar é o ato propulsor do conhecer, que só se estabelece a partir da dúvida, da desinformação, por que nos vemos insistindo, algumas vezes, em sermos facilitadores e não questionadores?

Ser um professor interdisciplinar $\mathrm{e}$, portanto questionador e atento ao cotidiano - é uma escolha que só se percebe quando já optamos por ela, um caminho sem volta. É quando acreditamos, porque sentimos assim, que o mundo nos possibilita aprendizagens em todos os momentos e tempos vividos, quando encontramos certezas provisórias que nos enchem de dúvidas ainda mais curiosas.

Então, assim, percebemos que todo sentir gera um significado, todo ato mostra uma direção, todo meio nos oferece respostas. Vivemos o tempo todo num exercício do pensar, do olhar aten- 
to e investigador.

Uma tarefa tão pessoal, introspectiva e, ao mesmo tempo, tão cercada de "gentes" virtuais (dos autores, dos teóricos, das lembranças, dos sonhos) e de "gentes" reais (dos colegas, dos professores, das conversas, das trocas acadêmicas, das farpas, dos afetos, do apoio, do conflito, da presença, da indiferença).

Percebemo-nos inteiros no tempo e no espaço, criando, observando, agindo, conhecendo, investigando, compreendendo, multiplicando, trocando. Desse modo, não nos sobra tempo para achar que não dá, ou pensar que não vale a pena. Como o Dom Quixote, de Cervantes, às vezes parecemos loucos; outras vezes, somos tidos como gênios. Nos dois casos, somos distantes o bastante para não nos fazermos possíveis, mas utópicos e sonhadores. E assim, como na história do cavaleiro, às vezes "vencidos por braços alheios, mas vencedores de si mesmos"(CERVANTES, s.d).

\section{REFERÊNCIAS}

BUBER, M. Eu e tu. Introdução e tradução de Newton Aquiles Von Zuben. São Paulo: Centauro, 1974.

CARNEIRO, R. G. M. Informática e educação: representações sociais do cotidiano. São Paulo: Cortez, 2002.

CERVANTES, M. de. Dom Quixote. Tradução de OrígenesLessa. São Paulo: Edições de Ouro, Editora Tecnoprint, s.d.

FAZENDA, I. Interdisciplinaridade: história , teoria e pesquisa. Campinas: Papirus, 1994.

(Org.). Interdisciplinaridade: dicionário em construção. São Paulo: Cortez, 2001.

. Os lugares dos sujeitos na pesquisas sobre interdisciplinaridade. In: TRINDADE, V.; FAZENDA, I.; LINHARES, C. (Org.). Os lugares dos sujeitos nas pesquisas educativas. Campo Grande: Editora UFMS, 1999.

FERREIRA, A. B. de H. Novo Aurélio Século XXI: o dicionário da língua portuguesa. Rio de Janeiro: Nova Fronteira, 1999.

JAPIASSÚ, H. Desistir do pensar, nem pensar !. Rio de Janeiro: Letras e Letras, 2001

PESSOA, F. A língua portuguesa. São Paulo: Companhia das Letras, 1999.

PIGNATARI, D. Contracomunicação. São Paulo: Perspectiva, 1971.

QUINTÁS, A. El secreto de una ensegnanza eficaz. Universidad Complutense, 2000 (mimeo).

Encaminhado em: 29/03/06

Aceito em: 28/04/06 